\title{
Biofuel derived from enzymatic degummed linum usitatissimum seed oil : as a potential resource for diesel engine
}

\author{
S. Kanakraj ${ }^{1 *}$, S. Dixit ${ }^{1 *}$ and A. Rehman ${ }^{2}$ \\ ${ }^{1}$ Department of chemistry, Maulana Azad National Institute of Technology, Bhopal (MP), India- 462051 \\ ${ }^{2}$ Professor, Department of mechanical engineering, Maulana Azad National Institute of Technology, Bhopal (MP), \\ India- 462051
}

\begin{abstract}
A bio-fuel derived from enzymatic degummed Linum usitatissimum seed oil (EDLO). We applied response surface methodology in order to optimize the reaction conditions of degumming process using microbial enzyme (Licitase ultra) in Linum usitatissimum seed oil, Enzyme dosage, temperature and reaction time were important determining factors affecting oil degumming. Optimum operating conditions were found to be reaction time of $5 \mathrm{~h}$, enzyme dosage of $1.6 \mathrm{wt} \%$ and temperature of $50^{\circ} \mathrm{C}$ at $\mathrm{pH}$ 5. At this optimum condition point the phosphorus content of degummed oil were found to be $7.8 \mathrm{mg} / \mathrm{kg}$. This study also discusses the EDLO-diesel fuel blends as a potential source for blend production. Furthermore, the blends of various proportions of EDLO:diesel,25:75, 35:65, 45:55 and 55: 45 were prepared, characterized and compared with diesel fuel. The fuel properties of EDLO25 diesel fuel blend was found comparable to those of diesel on the basis of experimental analysis..
\end{abstract}

Keywords: Enzymatic degumming; Linum usitatisimum seed oil; Diesel blend; Biofuel; fuel properties

\section{Introduction}

The energy crisis contributed the development of biofuel production. Fuel crisis and environmental concerns have renewed interest of the scientific community to look for alternative fuel of bio-origin such as vegetable oils. Biofuel is a less polluting and sustainable fuel derived from renewable sources such as vegetable oils, lipids, sugar and polysaccharides (Adebayo et al., 2011).The concept for producing fuel from vegetable oils for diesel engine is not radically new concept. In $1900 \mathrm{Mr}$. Rudolph diesel first tested his compression ignition engine on peanut oil as a fuel without any problem (Fangui et al.,1999, Parawira, 2010, Andrade et al., 2011). A number of problems were encountered in using straight vegetable oil (SVO) directly as a diesel engine fuel. The high viscosity of SVOs is the main cause reported in the literature for the problems encountered in engines. High SVO viscosity results in poor fuel atomization, incomplete combustion, and deposits in the combustion chamber (Pramanik, 2003). There are many appropriate methods for utilizing vegetable oils as fuels for diesel engines, such as dilution, blending, heating, transesterification and emulsification (Rathore et al., 2007) and degummed vegetable oil. Among these appropriate methods, degummed Linum usitatissimum seed oil is considered as an alternative fuel.

\section{Linum usitatissimum seed oil in India}

Linseed oil, its scientific name is Linum usitatissimum, belongs to the family Linaceae and the genus Linum. It originated and is cultivated in Canada, Argentina and India (Minor vegetal, 2011, Linseed basic, 2011). India is considered as the third largest producer of linseed in the world. In India linseed is mainly cultivated as rabi crop in with October-November being the main sowing season (Puhan et al., 2010). The various Indian states have sufficient forest area for the plantation of Linseed such as Uttar Pradesh, Maharashtra, Bihar, Rajasthan, Karnataka and West Bengal. Madhya Pradesh the center part of India is the leading producer of this crop. Madhya Pradesh and Uttar Pradesh together contribute to the national linseed production to the extent of about 70 per cent. (Linseed basic, 2011, Dixit et al., 2012). Fig. 1 shows the production of Linseed in India (IOPEPC,2013)

Influence of phospholipids (phosphorus) on vegetable oil based fuels

The phosphorus content in oil indicates the presence of phospholipids (gums). This parameter is very important for fuel use Indeed, phospholipids are responsible for the fouling of

\footnotetext{
*Corresponding author. e-mail: skskanakraj5@gmail.com
} 


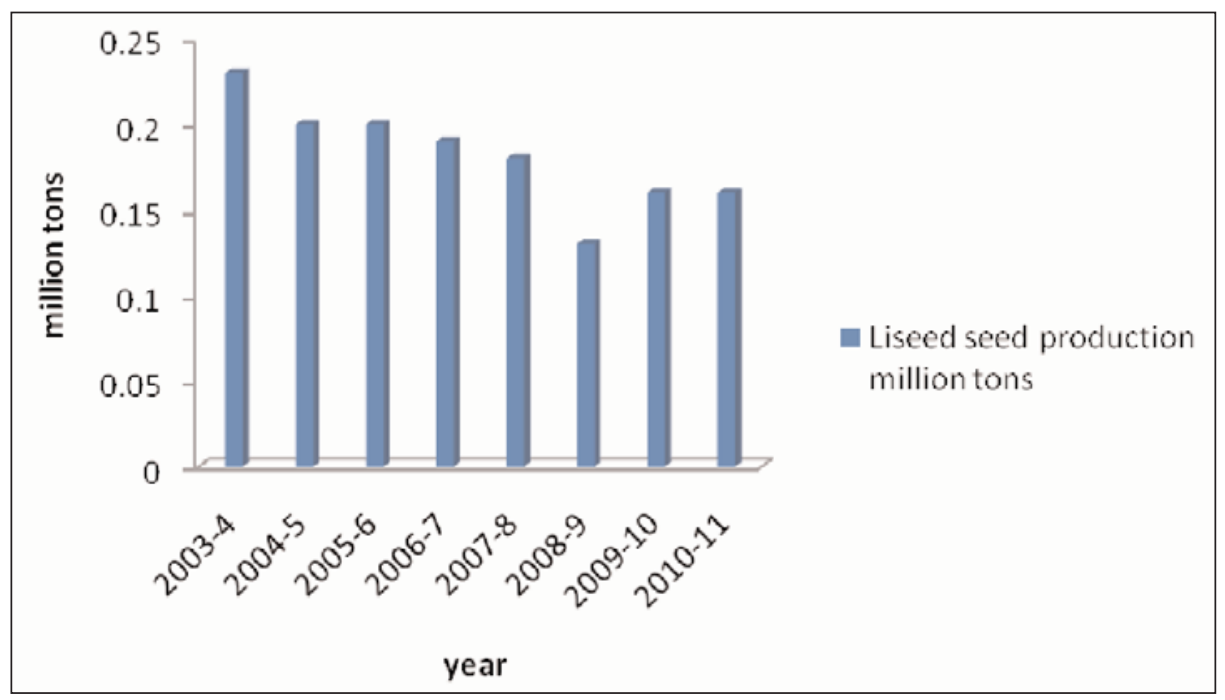

Fig. 1. Linseed seed production in India from 2003-2011(IOPEPC,2013)

valves, combustion chamber and cylinders when straight vegetable oils are used (gumming phenomenon) (Zufarov et al.,2008,Sidibe et al., 2010). Gums can cause problems during the transportation of fuels by settling and forming deposit on tanks walls or clogging pipelines (Fugue et al.,1999, Srivastava et al., 2000, Mullanix,2011). In engine where vegetable oil is used, excess phosphorus (gums) in the fuel can cause damage to catalytic converters since it can coat the inside of the converters or coking within the engine (Mullanix, 2011, Xiaohu et al., 2010) several researchers have also reported that formation of deposit in diesel engines (Ali et al., 1997, Zufarov et al., 2008). Therefore, it must be removed from the oil through an appropriate degumming process. There are several traditional degumming concepts have been introduced in the recent years to refining of vegetable oil including water degumming. Total degumming, ultra filtration process, acid degumming etc. cannot always achievement of phosphorus contents required for physical refining and are not always optimally suited for all oil qualities (Yang et al., 2006) Unfortunatly these methods have several disadvantages including corrosion of processing equipment; the yield loss, the equipment required and the energy expenditure of the process are also high (Prabharan et al., 2009). Enzymatic degumming is a suitable process for refining of oil. It is cost effective and very simple in opration as compared to traditional degumming process, this process does not alter the fatty acid composition of the oil (Yang and Yang et al., 2006) simple water degumming will not remove non-hydratable gums hence this degumming can be removed all type of gums from oil. This degumming has only been reported for rapseed, soyabean, sunflower and rice bran oils (Roy et al., 2002). But no work has been done for Linum usitatissimum seed oil. In this research, an attempt has been made to consider enzymatic degummed Linum usitatissimum seed oil as a fuel for compression ignition engines.

Chemistry of gum and enzymatic degumming:

\section{Gums}

Oil \& Fats contain complex organo-phosphorus compound referred to as phospholipids (phosphatides). All Vegetable Oils contains two types of gums (phospholipids), hydratable phospholipids (HPL) and non-hydratable phospholipids (NHPL), and they are removed from oil by degumming process (Zufarov et al., 2008). However, the amount of hydratable and non-hydratable gums vary significantly depending on a number of factors such as seed quality, seed type and oil milling conditions, but crude vegetable oil contains roughly $90 \%$ hydratable gums while the remaining $10 \%$ consists of non- hydratables. The basic structure of the phosphatides (phospholipids) given in Fig. 2. Phosphorus content in vegetable oils is analyzed and expressed in parts per million (ppm). This value is multiplied by the factor 25 to give the phosphatide content of the oil. This factor is derived from the ratio of the specific weight of phosphorus and the phosphatides (Hmm et al., 2002). Linum usitatissimum seed oil contains a high amount of phospholipids. The most important members of the lipids class found in this oil are phosphatidylethanolamine (PE) phosphatidyli 


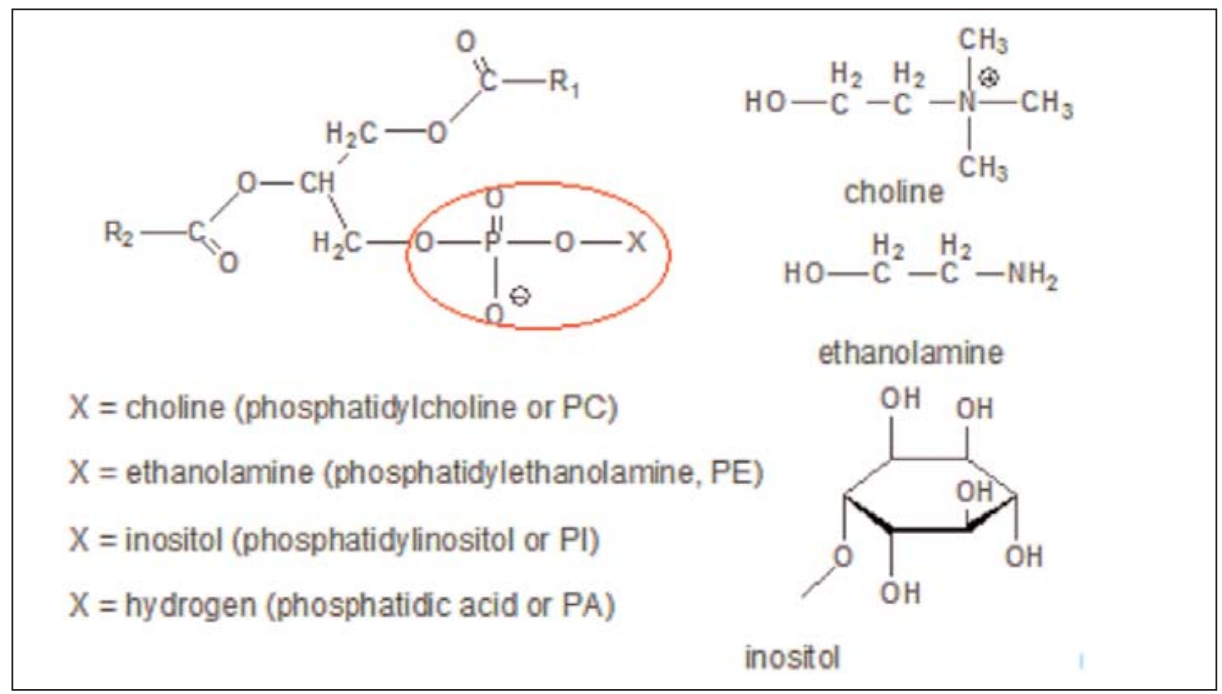

Fig . 2. Chemical structure of phospholipids

nositol (PI) and phosphotidylcholine (PC) (Heechi et al., 2012). Most of these (PC and PI phospholipids) are completely hydratable phospholipids and PE is partially hydratable. The objectives of the present work to analyze the effect of enzymatic degumming on reducing phospholipids from crude Linum usitatissimum seed oil and also discusses the EDLO- diesel fuel blends as a potential source for blend production.

\section{Enzymatic degumming}

In this process the Lecitase - Ultra (phospholipase A) hydrolyzed the Carboxylic group at $\mathrm{C} 1$ Position and nonhydratable or partially hydratable phospholipids in oil can initially be converted to fully hydratable phospholipid (lysophopholipids). The enzymatically hydrolyzed lysophospholipids are hydrophilic and mostly soluble in water.

\section{Materials and methods}

\section{Materials}

Mechanically expelled Linum usitassimum seed oil used in this experiment obtained from local market, commercially available diesel fuel was purchased from nearby petrol pump. Lecitase ultra (phospholipase enzyme) used as a degumming agent was purchased from Zytex biotech private limited Mumbai India. Other reagents were of analytical grade.

\subsection{Experimental setup}

The reactor used for experiments was a $500 \mathrm{ml}$ three-necked glass flask. The flask is placed on a water bath. The center neck is fitted with a stirrer. One of the two side necks is equipped with a thermometer and the other is closed by a

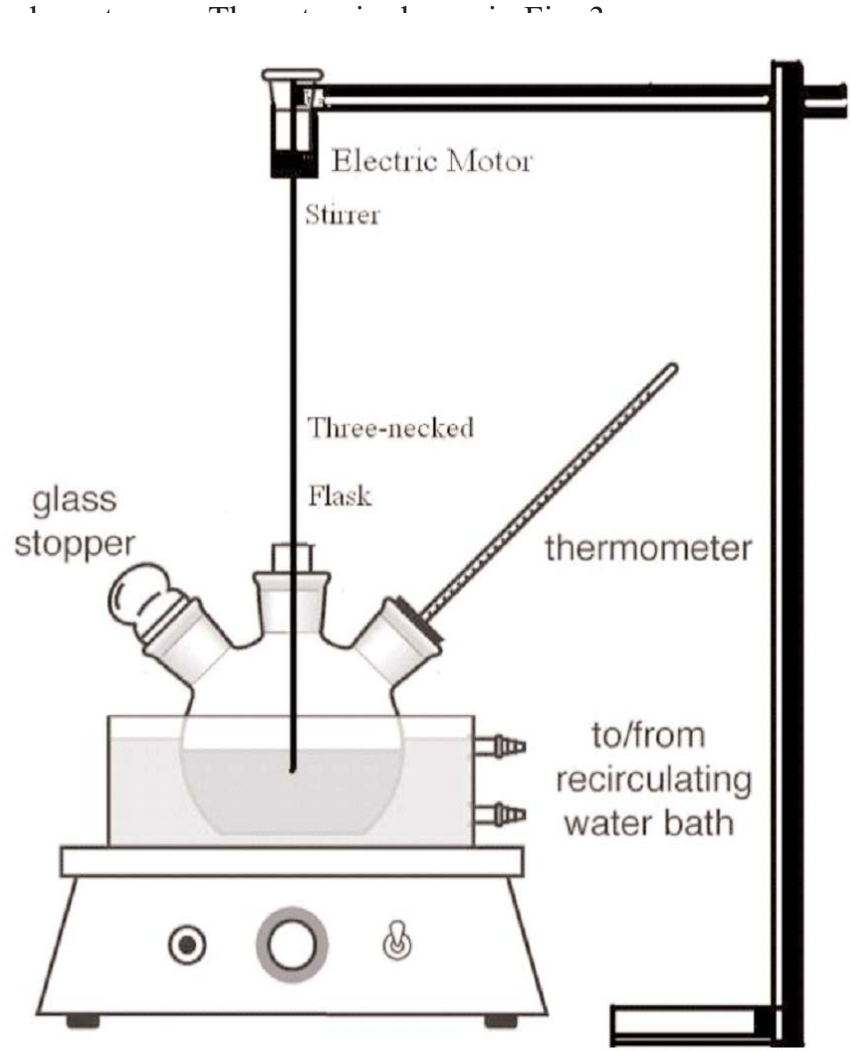

Fig. 3. Experimental set-up for preparation of degummed Linum usitatissimum seed oil 


\section{Methodology}

Enzymatic degumming of Linum usitatissimum seed oil

Measured quantity of Linum usitatissimum seed oil is taken in $500 \mathrm{ml}$ conical flask, and enzyme solution (100 ml buffer solution is prepared by dissolving $4 \mathrm{gm}$ of citric acid and 1.4 gm of caustic $(\mathrm{NaOH})$, the $\mathrm{PH}$ is adjusted to 4.8 to 5 and 350 to $400 \mathrm{mg}$ of enzyme is added to the buffer solution) is taken by pipette and added to the oil in different wt\% (0.6$2.2 \mathrm{wt} \%$ ) by using high shear mixer for $90 \mathrm{sec}$. the reaction mixture is transfer into the three-necked glass flask. The flask is kept in the water bath with slow agitation for incubation at temperature 40 to $50{ }^{\circ} \mathrm{C}$ with slow agitation for $3-5$ hours. After incubation the oil is heated to 75 to $80^{\circ} \mathrm{C}$ for 15 min to deactivate the enzyme. After deactivation of the enzyme, the oil was heated to $60^{\circ} \mathrm{C}$, and $1 \mathrm{wt} \%$ of hot deionized water is added into the reaction flask. The temperature of the system was maintained at $55^{\circ} \mathrm{C}$ for 15 minutes while the stirrer operating at $400 \mathrm{rpm}$. The mixture was then transferred to a centrifuge. Degummed oil was obtained after centrifuging for $1 \mathrm{~h}$ at $4500 \mathrm{rpm}$. Samples were drawn for phosphorus analysis Fig. 4. The optimal condition was identified based on the minimum residual phosphorus content in the degummed oil.
Experimental design and central composite design (CCD)

In order to optimize the reaction factors, a three-level threefactor central composite rotatable design (CCD) was utilized in this study. A CCD was applied three design factors, namely, Enzyme amount (A), Reaction temperature (B) and Reaction time $(\mathrm{C})$. The total number of experiments was 20 determined by the expression: $2^{n}\left(2^{3}=8\right.$ : factor points $)+2 n$ ( 2 X 3=6: axial points) +6 (center points: six replications). Table 1 describes the coded and uncoded levels of the independent variables, the test ranges for the parameter. The Design expert 8.0 software was used for regression and graphical analysis of the data obtained. The residual phosphorus content in the degummed oil was taken as the responses of the design experiment. Statistical analysis of the model was performed to evaluate the analysis of variance (ANOVA). Once the experiments are performed, the response variable was fitted a second- order model in to correct the response variable to the independent variable. The general form of the second-degree polynomial equation (Youn et al., 2008).

$$
Y=\beta_{0} \sum_{i=1}^{k} \beta_{i} x_{i}+\sum_{i=1}^{k-1} \sum_{j=2}^{k} \beta_{i j} x_{i} x_{j}+\sum_{i=1}^{k} \beta_{i i} x_{i}^{2}+e
$$

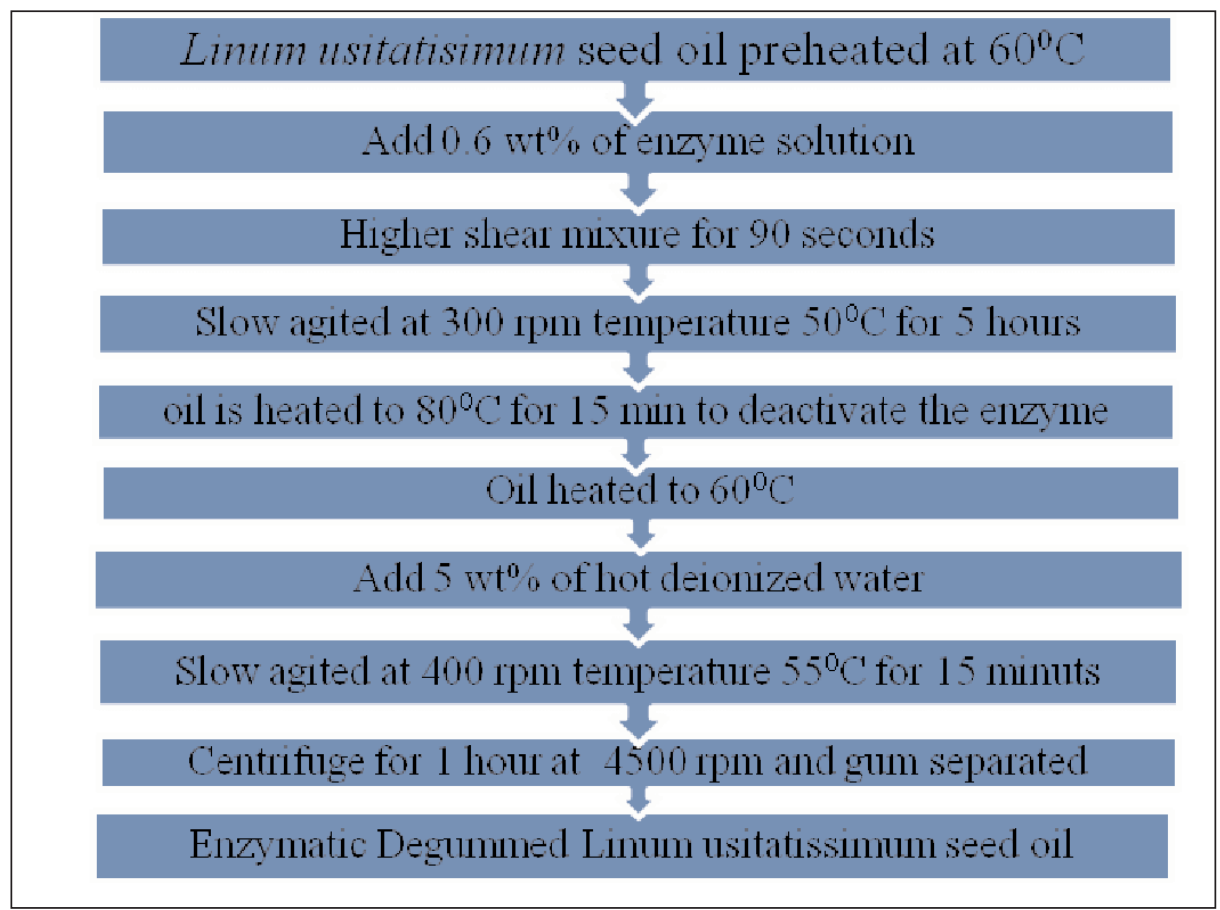

Fig. 4. Schematic diagram of simple procedure developed for the synthesis of enzymatic degummed Linum usitatissimum seed oil 
Table I. Factor and their level for response surface design

\begin{tabular}{lcccc}
\hline Factors & \multicolumn{2}{c}{ Symbol Range } & \multicolumn{2}{c}{ and levels } \\
\hline & & -1 & 0 & +1 \\
Enzyme amount Wt\% & $\mathrm{A}$ & 0.6 & 1.6 & 2.2 \\
Reaction Temperature & $\mathrm{B}$ & 40 & 45 & 50 \\
Reaction time Hour & $\mathrm{C}$ & 3 & 4 & 5 \\
\hline
\end{tabular}

Where $\mathrm{Y}$ is the predicted response $\beta_{0}$ and the offset term, $\beta_{\mathrm{i}}$ the linear effect, $\beta_{\mathrm{ij}}$ the squared effect and $\beta_{\mathrm{jj}}$ is the interaction effect, $\mathrm{n}$ is the number of significant independent variable A, B and C(Jeong et al., 2009).

Enzymatic degummed Linum usitatissimum seed oil and diesel fuel blending

Different blends of EDLO with conventional diesel fuel were prepared. The fuel properties of the EDLO and diesel fuel are presented in Table 6. The EDLO was blended with diesel fuels at $25 \%, 35 \%, 45 \%$ and $55 \%$ on a volume basis. In order to determine the properties of the diesel fuels, the EDLO and its diesel blends, the following test methods were used, Density at $15^{\circ} \mathrm{C}$ (IS: 1448:[P:16]:1990), Viscosity at 40 ${ }^{\circ} \mathrm{C}$ (IS:1448:[P:25]:1976), Pour point (ASTM D97), Flash point (ASTM D93), Calorific value measured by Bomb calorimeter (ASTM- D240), Acid number (AOCS Cd 3a64), Phosphorus (AOCS Official method Ca 12-55), cloud point (ASTM 2500). Some EDLO-diesel blends given below in Table II. For proper mixing of EDLO with diesel fuel, it important to first pour the diesel fuel in the container and then the EDLO is added. Stirring should be done for few seconds. Blending improves fuel properties to suit the CI engine operation.

Table II. EDLO -diesel blends

\begin{tabular}{ll}
\hline Sample & Blending with diesel \\
\hline EDLO25 & $25 \%$ EDLO and $75 \%$ diesel \\
EDLO35 & $35 \%$ EDLO and $65 \%$ diesel \\
EDLO45 & $45 \%$ EDLO and $55 \%$ diesel \\
EDLO55 & $55 \%$ EDLO and $45 \%$ diesel
\end{tabular}

\section{Results and discussion}

3.1Effect of Enzymatic degumming method on phosphorus (phospholipids) content in Linum usitatissimum seed oil

The amount of phospholipids was determined as the total phosphorus in oil according to AOCS official method ca 12-55. ASTM D 6751-09 requires the maximum amount of 10 ppm phosphorus content in the final biodiesel fuel. Degumming was removed phospholipids (phosphatides) and lowered down phosphorus content in the Linum usitatissimum seed oil.The residual phosphorus content in enzymatic degummed oil is about 7.8 ppm after enzymatic degumming which meet the phosphorus level requirement as proposed by the ASTM standard. Straight LO presents the highest phosphorus concentration (100 ppm) Phosphatide content in EDLO.

Optimization of Reaction condition of Response surface Methodology for EDLO synthesis.

Table III describes the experimental parameters and their results, on the basis of the CCD experimental design. Regression analysis yield three linear coefficients $(A, B, C)$, three quadratic coefficients $\left(\mathrm{A}^{2}, \mathrm{~B}^{2}, \mathrm{C}^{2}\right)$, and three cross product coefficients (AB, AC, BC) for the full model (Table IV). Table IV also describes the ANOVA for the response surface quadratic model.

Table III. Full-factorial central composite design matrix of three variables in coded and natural units along with the observed responses.

\begin{tabular}{|c|c|c|c|c|c|}
\hline Run & $\begin{array}{c}\text { Variable } \\
\text { in coded } \\
\text { levels }\end{array}$ & $\begin{array}{c}\text { Enzyme } \\
\text { amount } \\
\mathrm{Wt}^{\circ} \%\end{array}$ & $\begin{array}{c}\text { Reaction } \\
\text { tempera- } \\
\text { ture }{ }^{\circ} \mathrm{C}\end{array}$ & $\begin{array}{c}\text { Reaction } \\
\text { time } \\
\text { hour }\end{array}$ & $\begin{array}{c}\text { Phosphorus } \\
\text { (mg/kg) } \\
\mathrm{Y}\end{array}$ \\
\hline & A B C & & & & \\
\hline 1 & & 1.6 & 45 & 4 & 14.2 \\
\hline 2 & & 1.6 & 40 & 4 & 16.5 \\
\hline 3 & & 1.6 & 50 & 4 & 13.2 \\
\hline 4 & & 1.6 & 45 & 4 & 14 \\
\hline 5 & & 0.6 & 50 & 5 & 11.9 \\
\hline 6 & & 2.2 & 40 & 3 & 19.8 \\
\hline 7 & & 2.2 & 50 & 5 & 7.8 \\
\hline 8 & & 0.6 & 40 & 5 & 16 \\
\hline 9 & & 1.6 & 45 & 4 & 14.2 \\
\hline 10 & & 0.6 & 50 & 3 & 17 \\
\hline 11 & & 1.6 & 45 & 3 & 17 \\
\hline 12 & & 1.6 & 45 & 4 & 14.1 \\
\hline 13 & & 1.6 & 45 & 5 & 9.6 \\
\hline 14 & & 2.2 & 50 & 3 & 15 \\
\hline 15 & & 2.2 & 45 & 4 & 14.1 \\
\hline 16 & & 1.6 & 45 & 4 & 14 \\
\hline 17 & & 2.2 & 40 & 5 & 12.1 \\
\hline 18 & & 0.6 & 40 & 3 & 25 \\
\hline 19 & & 0.6 & 45 & 4 & 18 \\
\hline 20 & & 1.6 & 45 & 4 & 14.2 \\
\hline
\end{tabular}


Table IV. Analysis of variance (ANOVA) for the quadratic model

\begin{tabular}{lccccc}
\hline Source of variations & Sum of squares & Degree of freedom & Mean square & F- value & Prob $>$ F \\
\hline Model & 247.96 & 9 & 27.55 & 96.13 & $<0.0001$ \\
A & 36.48 & 1 & 36.48 & 127.29 & $<0.0001$ \\
B & 60.87 & 1 & 60.87 & 121.38 & $<0.0001$ \\
C & 131.72 & 1 & 131.72 & 459.57 & 0.0001 \\
AB & 1.43 & 1 & 1.43 & 4.98 & 0.0497 \\
AC & 0.085 & 1 & 0.085 & 0.30 & 0.5979 \\
BC & 2.42 & 1 & 2.42 & 8.44 & 0.0157 \\
A $^{2}$ & 4.66 & 1 & 4.66 & 16.27 & 0.0024 \\
B $^{2}$ & 0.96 & 1 & 0.96 & 3.35 & 0.0971 \\
C $^{2}$ & 2.53 & 1 & 2.53 & 8.83 & $<0.0140$ \\
Residual & 2.87 & 10 & 0.29 & & 0.0002 \\
Lack of fit & 2.82 & 5 & 0.56 & 58.30 & \\
Pure error & 0.048 & 5 & $9.66 \mathrm{E}-003$ & & \\
Total & 250.83 & 19 & & & \\
\hline
\end{tabular}

The final value estimate response model equation (based on the final empirical value), by which we analyzed EDLO synthesis, was as Follows:

$\mathrm{Y}=14.56-1.91 \mathrm{~A}-2.47 \mathrm{~B}-3.63 \mathrm{C}+0.42-0.10 \mathrm{AC}+0.55 \mathrm{BC}$

$1.40 \mathrm{~A}^{2}+0.59 \mathrm{~B}^{2}-0.96 \mathrm{C}^{2}$

In which $\mathrm{Y}$ is the response factor, (EDLO) content wt $\%, \mathrm{~A}$, $\mathrm{B}, \mathrm{C}$ are the value of the three independent variable, enzyme amount $(w t \%)$, Reaction temperature and reaction time (minutes). The model coefficient values are provided in Table V. The 3D response surface plots are generally represent the graphical representations of the regression equation are presented in Fig. 5 (a,b,c,). The 3D response surface in Fig. 5(a) show that there is a response surface plots represent

Table V. Regression coefficient and significance of response surface quadratic model

\begin{tabular}{lcccccc}
\hline Factor & $\begin{array}{c}\text { Coefficient df } \\
\text { estimate }\end{array}$ & $\begin{array}{c}\text { Standard } \\
\text { error }\end{array}$ & $\begin{array}{c}95 \% \\
\text { CI low }\end{array}$ & $\begin{array}{c}95 \% \mathrm{CI} \\
\text { high }\end{array}$ & VIF \\
\hline Intercept & 14.56 & 1 & 0.20 & 14.13 & 15.0 & 1.03 \\
$\mathrm{~A}$ & -1.91 & 1 & 0.17 & -2.29 & -1.53 & 1.00 \\
$\mathrm{~B}$ & -2.47 & 1 & 0.17 & -2.85 & -2.09 & 1.00 \\
$\mathrm{C}$ & -3.63 & 1 & 0.17 & -4.01 & -3.26 & 1.00 \\
$\mathrm{AB}$ & 0.42 & 1 & 0.19 & $6.290 \mathrm{E}-004$ & 0.84 & 1.00 \\
$\mathrm{AC}$ & -0.10 & 1 & 0.19 & -0.52 & 0.32 & 1.00 \\
$\mathrm{BC}$ & 0.55 & 1 & 0.19 & 0.13 & 0.97 & 1.00 \\
$\mathrm{~A}^{2}$ & 1.40 & 1 & 0.35 & 0.63 & 2.17 & 1.85 \\
$\mathrm{~B}^{2}$ & -0.59 & 1 & 0.32 & -0.13 & 1.31 & 1.82 \\
$\mathrm{C}^{2}$ & -0.96 & 1 & 0.32 & -1.68 & -0.24 & 1.82 \\
\hline
\end{tabular}

ing the effects of reaction temperature, enzyme amount and their reciprocal interaction on EDLO synthesis. Other factor is constant. Fig. 5b indicated that the effects of reaction time, enzyme amount and their reciprocal interaction on EDLO synthesis and Fig. 5c shows that there is a significant mutual interaction between reaction time, reaction temperature on EDLO synthesis. The optimal conditions for EDLO synthesis from crude Linum usitatissimum seed oil as estimated by the model equation, were as follows: A (enzyme amount) $=1.6 \mathrm{wt} \%$, $\mathrm{B}$ (Reaction temperature $)=50$ and $\mathrm{C}$ (reaction time $)=5 \mathrm{~h}$. The model predicts that the minimum phosphorus content in degummed oil that can be obtained under the above optimum conditions of the variables is $7.8 \mathrm{mg} / \mathrm{kg}$.

Fuel related properties of EDLO-diesel blends

Density

In this study the density of EDLO- diesel blends are very close to each other and range from 0.849 to $0.890(\mathrm{~g} / \mathrm{ml})$ at $15^{\circ} \mathrm{C}$ and they are slightly higher than those of the diesel fuel as seen in Table III Fig.6a, presents the density values of EDLO diesel blends. There is a linear increase in the density of the blends as the amount of EDLO increases. Hence, the density of $25 \%$ EDLO is comparable to that of diesel fuel.

\section{Kinematic viscosity}

The viscosity of the blend increases as the EDLO amount increases in the fuel mixture as observed from Fig. $6 \mathrm{~b}$ the 


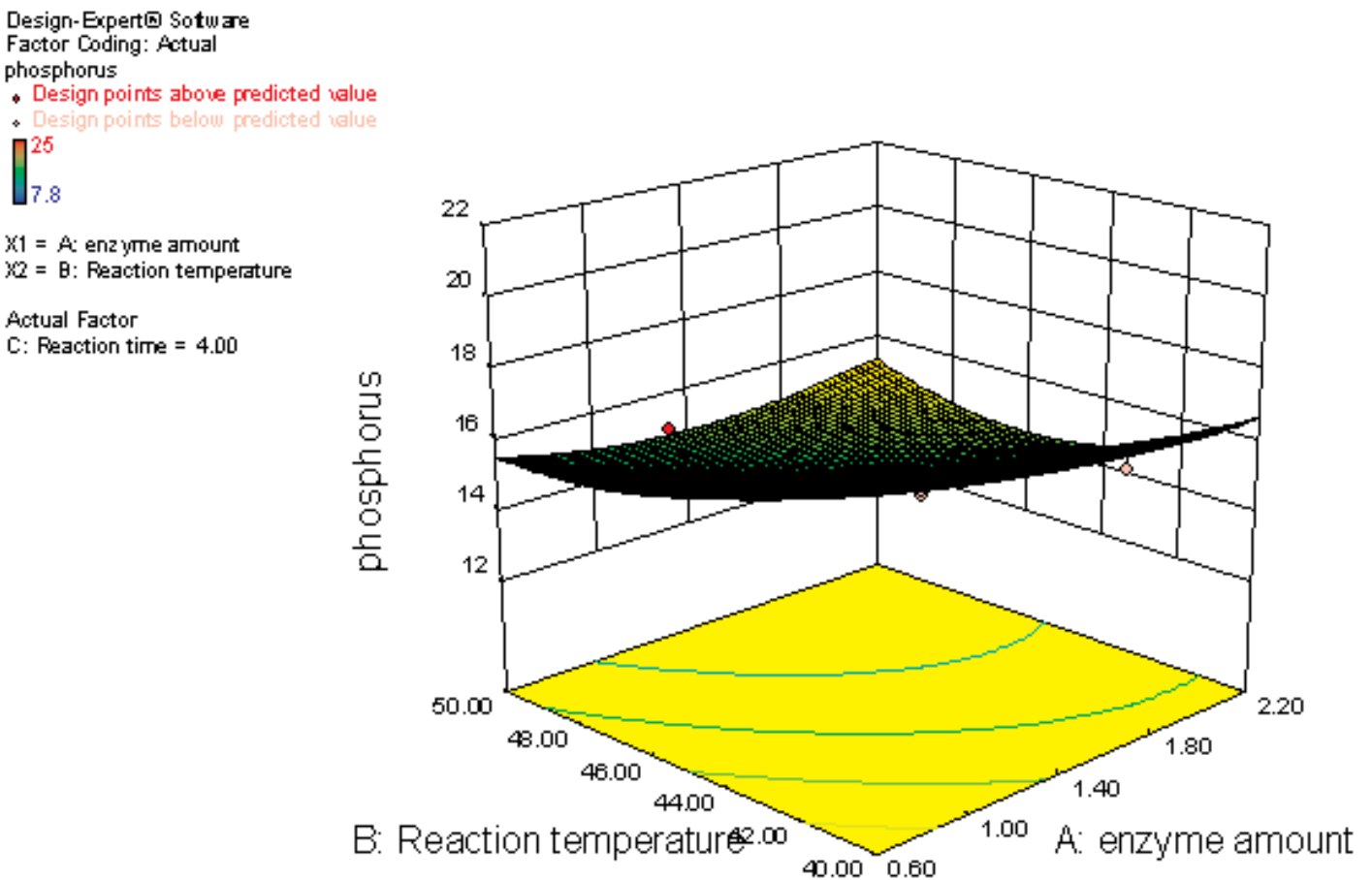

Fig. 5(a). Response surface plots representing the effects of reaction temperature, enzyme amount, and their reciprocal interaction on EDLO synthesis. Other factor is constant

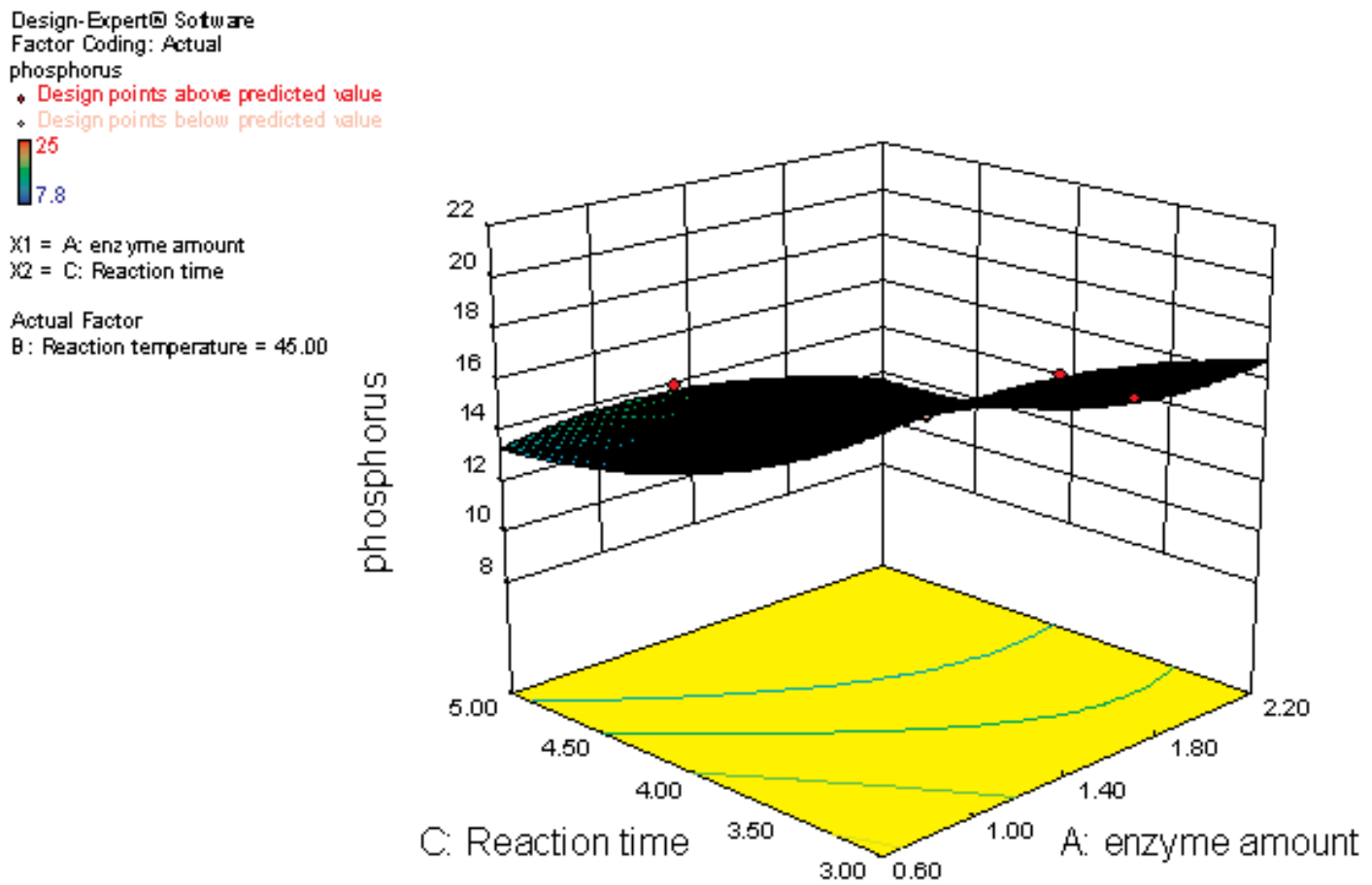

Fig. 5(b). Response surface plots representing the effects of reaction time, enzyme amount and their reciprocal interaction on EDLO synthesis. Other factor is constant 


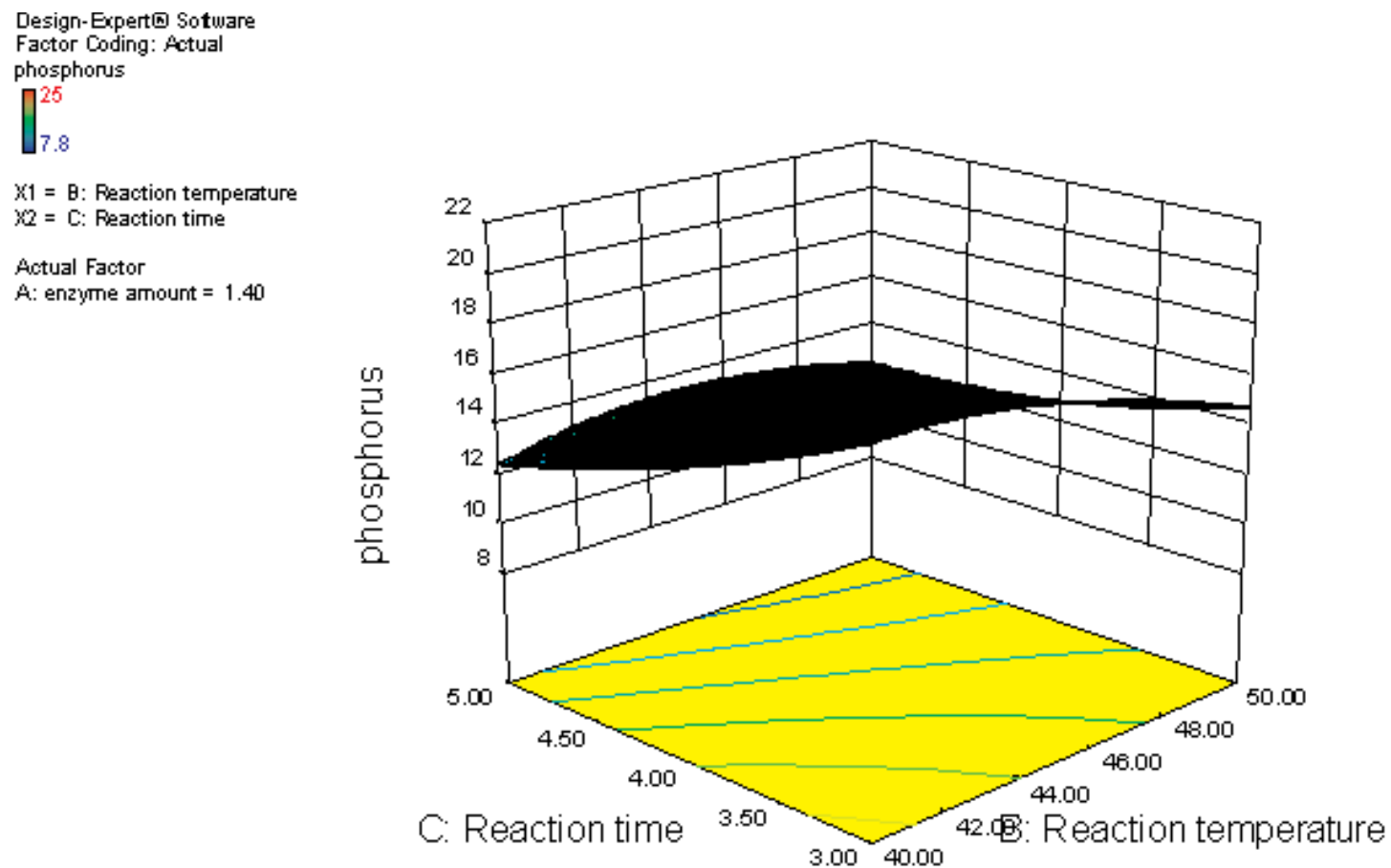

Fig. 5(c). Response surface plots representing the effects of reaction temperature, reaction time and their reciprocal interaction on EDLO synthesis. Other factor is constant

viscosity of EDLO was observed to be higher than that of diesel fuels but the viscosity of $25 \%$ EDLO is very close to that of diesel fuel as given in Table III. The Indian standard (IS: 1448 [p: 25] 1976) recommends the range of the viscosity of diesel from 2 to $4 \mathrm{cSt}$ for the use in high speed diesel engines. Thus the comparison of the viscosity of EDLO and its blends suggests that EDLO can be blended with diesel in proportion of $25 \%$ to meet the viscosity requirement as proposed by Bureau of Indian Standards (IS: 1448 [p: 25]).

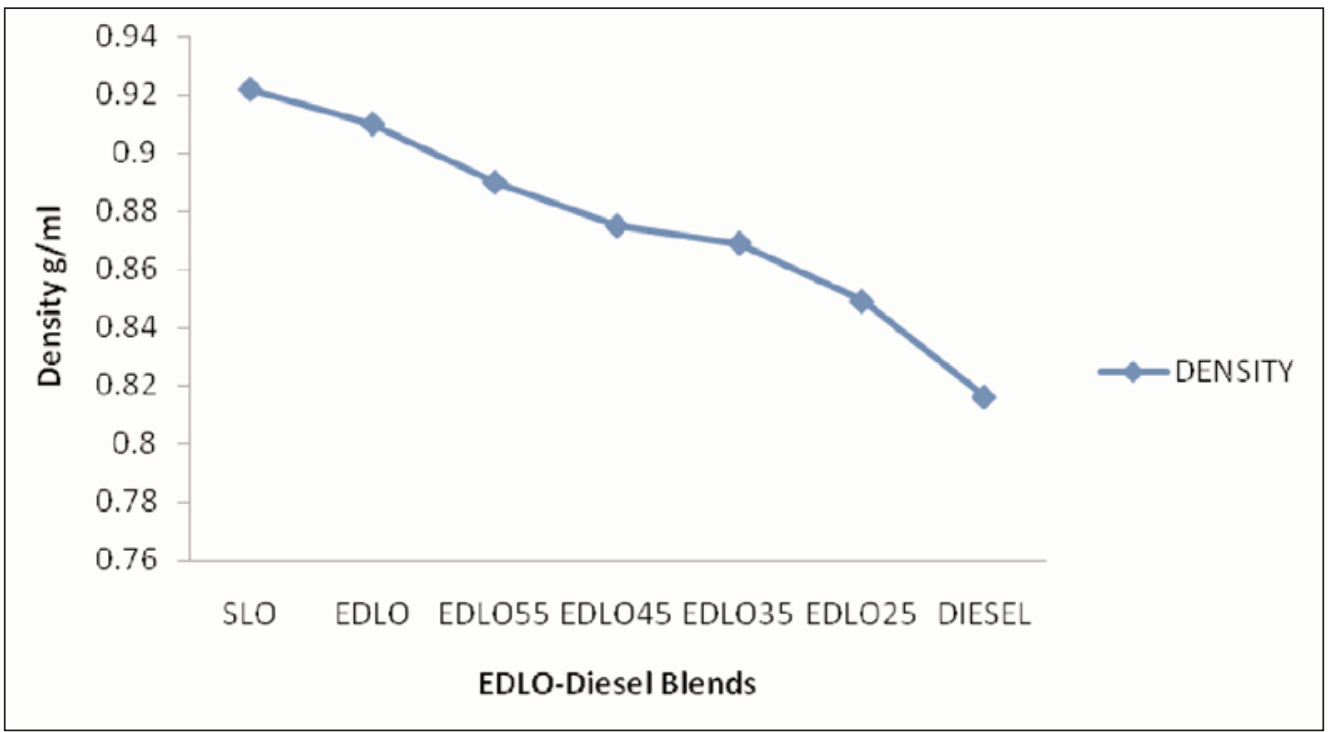

Fig. 6a. Density of EDLO -diesel fuel blends 


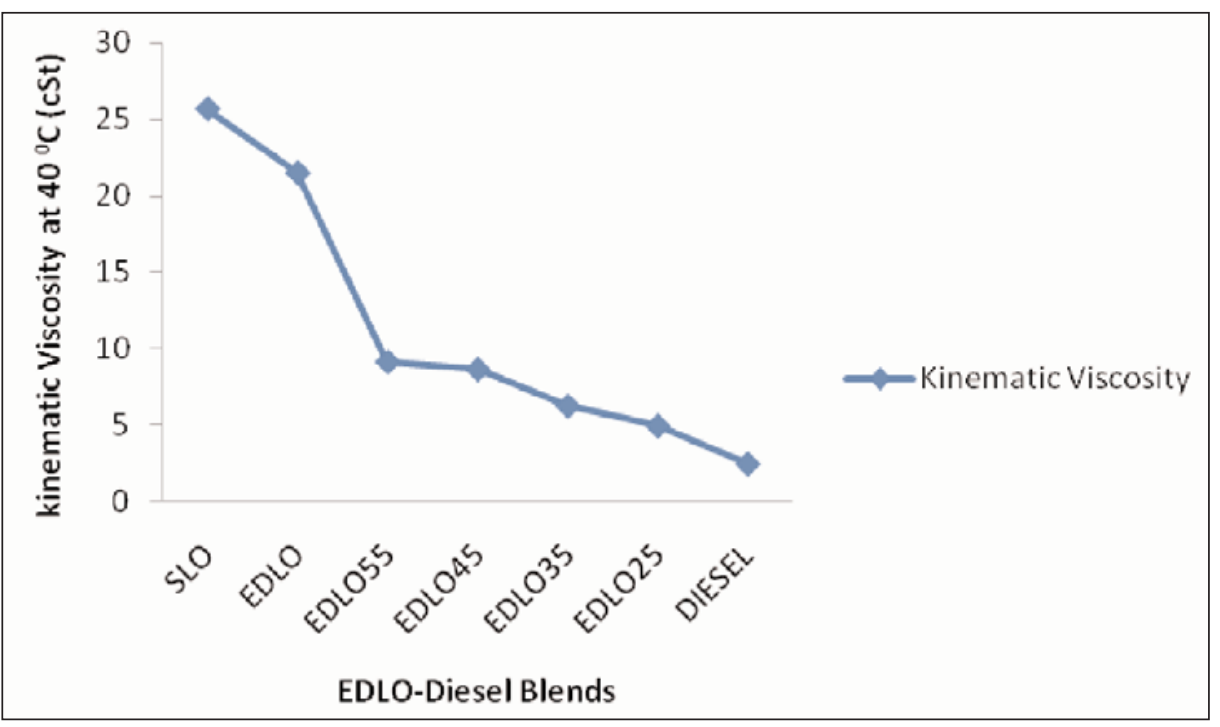

Fig. 6b. KinematicViscosity of EDLO-Diesel

\section{Cloud and Pour point}

The cloud and pour point are of great importance to engine operating in cold climate. Both properties may also indicate the tendency towards filter plugging and flow problems in the fuel line. The cloud and pour points of the blends demonstrated an increase as the concentration of EDLO increases in relation to the diesel fuels, as given in Fig.7a. According to these results, the cloud and pour point of EDLO can be reduced significantly by blending it with diesel fuel, which means that the fuel flow will be improved in the fuel injection system at low temperature.

\section{Flash and fire points}

These are the properties, which shall be considered in assessing the flammability and hazard of fuel. The flash and fire point of EDLO are much higher than those of diesel fuels but it's both flash and fire point of diesel can be improved by blending it with EDLO as shown in Table III and Fig.7b.

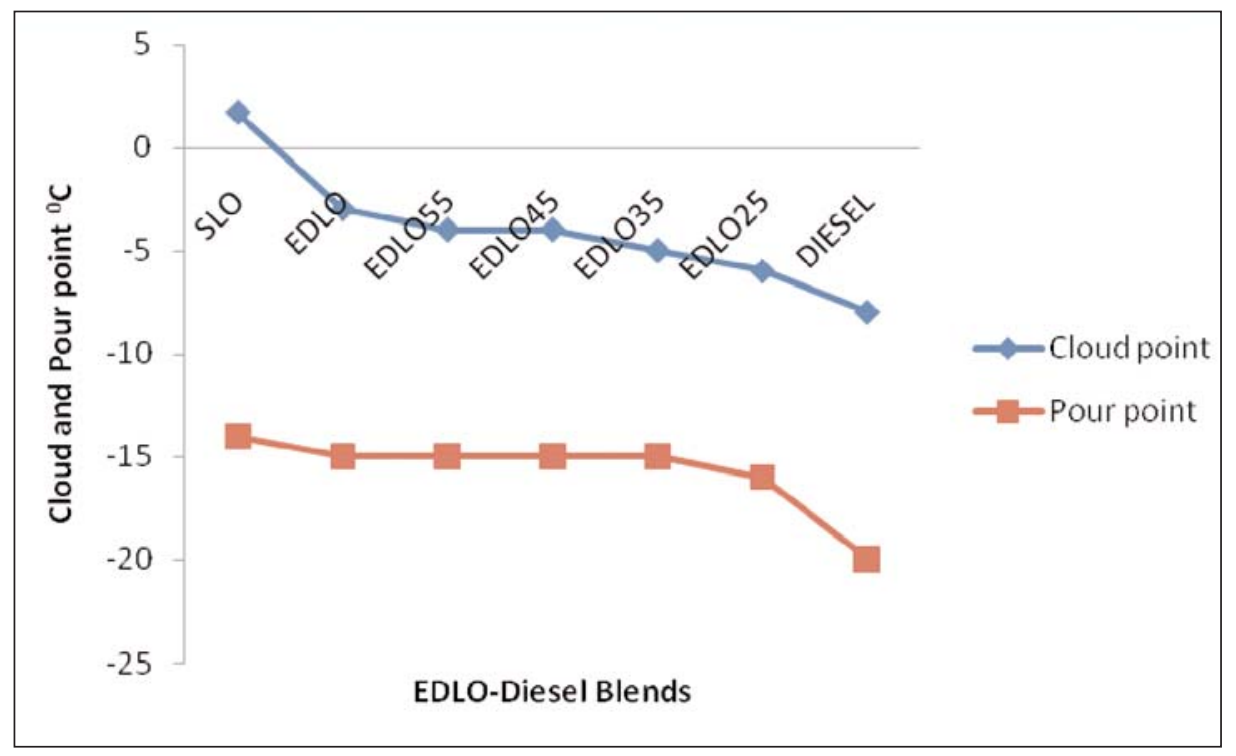

Fig.7a. Cloud and Pour point of EDLO-diesel blends 


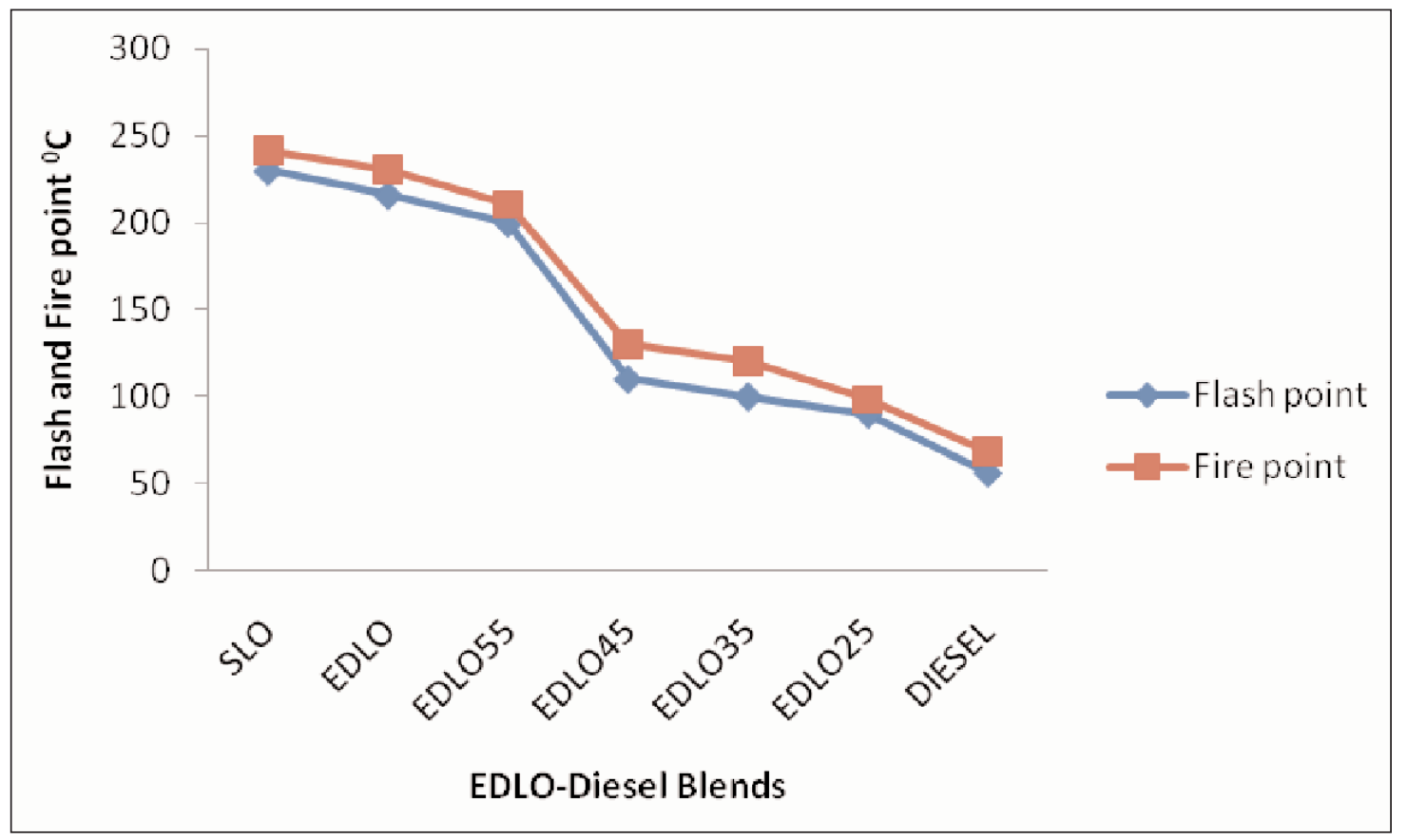

Fig.7b. Flash and Fire point of EDLO-diesel blends

Table VI. Fuel properties of Diesel,Straight Linum usitatissimum seed oil and EDLO -diesel blends

\begin{tabular}{|c|c|c|c|c|c|c|c|}
\hline \multirow[t]{2}{*}{ Fuel parameter } & \multirow{2}{*}{$\begin{array}{l}\text { Straight Linum } \\
\text { usitatissimum } \\
\text { seed oil (SLO) }\end{array}$} & \multirow{2}{*}{$\begin{array}{l}\text { Enzymatic degummed } \\
\text { Linum usitatissimum } \\
\text { seed oil (EDLO) }\end{array}$} & \multicolumn{4}{|c|}{ EDLO- Diesel blends } & \multirow[t]{2}{*}{ Diesel } \\
\hline & & & EDLO55 & EDLO45 & EDLO35 & EDLO25 & \\
\hline $\begin{array}{l}\text { Density at } \\
15^{\circ} \mathrm{C}(\mathrm{g} / \mathrm{ml})\end{array}$ & 0.922 & 0.910 & 0.890 & 0.875 & 0.869 & 0.849 & 0.816 \\
\hline $\begin{array}{l}\text { Kinematic viscosity } \\
(\mathrm{cSt}) \text { at } 40^{\circ} \mathrm{C}\end{array}$ & 25.7 & 21.5 & 9.1 & 8.6 & 6.2 & 4.9 & $2.4-4$ \\
\hline $\begin{array}{l}\text { Calorific value } \\
(\mathrm{MJ} / \mathrm{kg})\end{array}$ & 39.63 & 40.1 & 40.9 & 41.45 & 41.65 & 41.95 & 45.71 \\
\hline Flash point ${ }^{\circ} \mathrm{C}$ & 230 & 215 & 200 & 110 & 100 & 90 & 55 \\
\hline Fire point ${ }^{\circ} \mathrm{C}$ & 241 & 225 & 210 & 130 & 115 & 95 & 68 \\
\hline Cloud point ${ }^{\circ} \mathrm{C}$ & 1.7 & -3 & -4 & -4 & -5 & -6 & -8 \\
\hline Pour point ${ }^{\circ} \mathrm{C}$ & -14 & -15 & -15 & -15 & -15 & -16 & -20 \\
\hline Acid value mg & & & & & & & \\
\hline $\mathrm{KOH} / \mathrm{g}$ & 1.0 & 0.85 & 0.84 & 0.84 & 0.84 & 0.84 & 0.22 \\
\hline $\begin{array}{l}\text { Saponification value } \\
\mathrm{mg} \mathrm{KOH} / \mathrm{g}\end{array}$ & 188 & 182 & & & & & \\
\hline
\end{tabular}




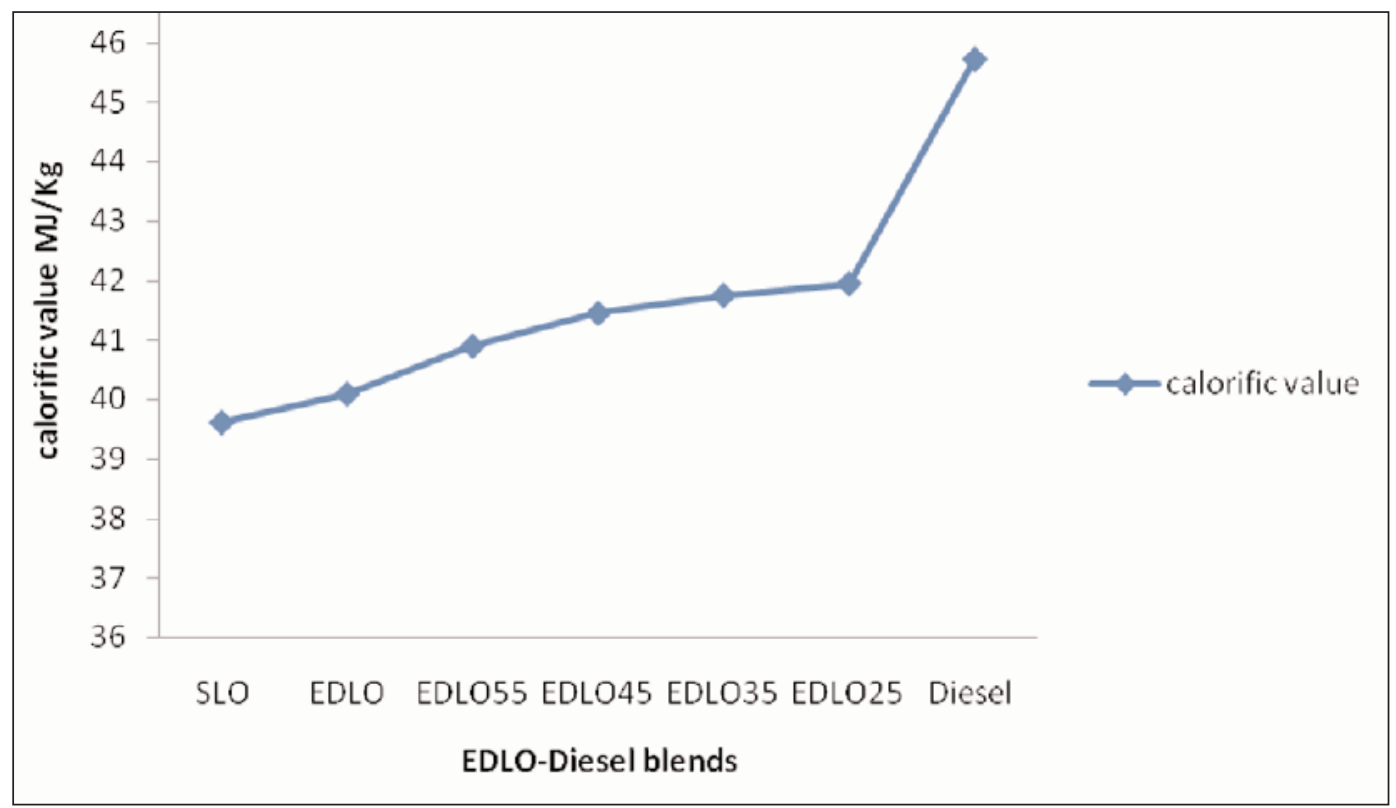

Fig. 8. Calorific value of EDLO -diesel fuel blends

Calorific value

The calorific value is an important property defining the energy content and thereby the efficiency of fuels. Calorific value for the EDLO- diesel blends was observed. It was found that EDLO25 blends calorific value is very close to that of diesel fuel. As observed in Fig.8

\section{Conclusion}

The enzymatic degummed Linum usitatissimum seed oil is chosen as a potential non-edible vegetable oil for the production of biofuel. This process not only reduced the phosphorus (gm) content of the Linum usitatissimum seed oil from $100 \mathrm{ppm}$ to $7.8 \mathrm{ppm}$ but also it can prove to be an effective method of enhanced its fuel properties. As a general conclusion, the enzymatic degumming is an environment friendly method for the removal of gums from vegetable oil and it is suggested as a way to use non-esterified Linum usitatisimum seed oil in diesel engine. India is considered as the third largest producer of Linseed (Linum usitatissimum seed) in the world. Madhya Pradesh the central part of India is the leading producer of this crop. In the near future, Enzymatic degummed Linum usitatissimum seed oil can be expected as a potential energy resource for diesel engine in India.

\section{Acknowledgements}

The authors wish to acknowledge the financial support received from Madhya Pradesh council of Science and Technology (MPCST) Bhopal M.P, India. And I am very thankful to Dr. Appu Kuttan K.K. Director, M.A.N.I.T., Bhopal.

\section{References}

Adebayo GB, Ameen OM and Abass LT (2011), Physicochemical properties of biodiesel produced from jatropha Curcas oil and fossil diesel. J. Microbiol. Biotech.Res. Sch. 1(1): 12-16.

Ali Y and Hanna M (1994), Alternative diesel fuels from vegetable oils. Bio. Res. Technol 50(2):153-63 .

Andrade JE, Perez A, Sebastian PJ and Eapen D (2011), A review of biodiesel production process. Biomass Bioenergy. 35: 1008-20.

Dixit S, Kanakraj S and Rehman A (2012), Linseed oil as a potential resource for biodiesel: a review. Renew Sust Energ Rev.16: 4415-4421.

Fangui M and Hanna Milford A (1999), Biodiesel production: review. Bio. Res. Technol. 70: 1-15. 
Heechi W, Arraez RD, Boukhchina S and Kallel H (2012), A review of the methods used in the determination of flaxseed components. $A J B$, 11(40): 724-731( 2012).

Hmm W, Hamilton RJ and Cook R (2002), Edible oil processing.SHEFFELD Academic press and CRC press, 84-85.

Indian oilseeds production (millions) (2013), IOPEPC, www.iopepc.org/Indian\%20oilseed\%20production.pdf 2013:26 March

Jeong G and Park D (2009), Optimization of the biodiesel production from castor oil using response surface methodology. Appl Biochem Biotechnol. 156: 431-441.

Linseed Basic (2011), http://www.pnbkrishi.com/ linseed.htm. Accessed 12 Nov.

Minor Vegetal oil (2011), http://www.cyberlipid. org/glycer/glyc0053.htm. Accessed 22 Nov.

Mullenix DK (2011), Optimization and economics of smallscall, on farm biodiesel production using oilseed crops and waste vegetable oil, Auburn Alabama.

Parawira W (2010), Bio-diesel production from Jatropha curcus: a review. Sci. essys. 5(14):1796-1808 .

Prabhaharan M, Rakshit SK (2009), Optimize the condition for enzymatic degumming of crude soybean oil, Tropic Agriculture Research And Extension .12(2) .

Pramanik K (2003), Properties and use of Jatropha curcas oil and diesel fuel blends in compression ignition engine. Renew Energ. 28 (10): 239-248.

Puhan S, Saravanan N, Nagarajan G and Vedaraman N (2010), Effect of biodiesel unsaturated fatty acid on combustion characteristics of a DI compression ignition engine. Biomass Bioenergy. 34: 1079-1088.
Rathore V and Madras G (2007), Synthesis of bio-diesel from edible and non-edible oils in supercritical alcohols and enzymatic synthesis in supercritical carbon dioxide. Fuel. 86: 2650-9.

Roy SK, Rao BVSK. Rao, Prasad RBN. Prasad (2002), Enzymatic degumming of rice bran oil. JAOCS. 79: 845-846.

Sidibe SS, Blin J, Vaitilingom G and Azoumah Y (2010), Use of crude filtered vegetable oil as a fuel in engines state of the art: Literature review. Renew Sust Energ Rev.14: 2748-2759.

Srivastava A and Parasad R (2000), Triglycerides-based diesel fuels. Renew Sust Energ Rev. 4:111-33.

Xiaohu F, Rachel B and Greg A (2010), Conversion of Degummed soybean oil to biodiesel: Optimization of Degumming method and evaluation of fuel properties. Int. J. of green energy. 7: 593-599 .

Yang BY, Wang YH and Yang J (2006), Optimization of degumming process for rapeseed oil. JAOCS.83:7 .

Yang J, Wang YH, Yang B, Geoffrey mainda, yong guo (2006), Degumming of vegetable oil by a new microbial lipase, degumming of oil, Food Technol.Biotechnol.44(1): 101-104.

Youn X, Liu J, Zeng G, Shi J, Tong J and Huang G (2008), Optimization of conversion of waste rapeseed oil with high FFA to biodiesel using response surface methodology. Renewable Energy. 33:1678-1684.

Zufarov O,Schmidt S and Seketar S (2008), Degumming of rapeseed and sunflower oils. Acta chim slov.1: 321328 .

Received: 10 March 2013; Revised: 27 November 2013; Accepted: 17 December 2013. 